\title{
Clarifying competition: the case of wildlife and pastoral livestock in East Africa
}

\author{
Bilal Butt ${ }^{1^{*}}$ and Matthew D Turner ${ }^{2}$
}

\author{
* Correspondence: bilalb@umich.edu \\ ${ }^{1}$ School of Natural Resources and \\ Environment, University of \\ Michigan, Ann Arbor Ml \\ 48109-1041, USA \\ Full list of author information is \\ available at the end of the article
}

\begin{abstract}
Contentious debates surrounding the relationship between peoples' livelihoods and protected areas in East Africa have largely revolved around claims and counter-claims about the level of competition between pastoral livestock and wildlife. Habitat and dietary overlap are often cited as the primary mechanism by which competition occurs with both overlap and lack of overlap (displacement) used as evidence of competition. Despite the importance of this issue for the economic and environmental futures of the region, there has been little scientific progress for understanding the nature of livestock-wildlife competition in pastoral landscapes. This article seeks to add conceptual clarity to this debate by focusing attention on exploitation competition in ways that are relevant to dryland East Africa. The article begins by briefly reviewing the changing understandings of the concept of competition in ecology. Requirements of competition, as defined in the literature, are then related to the ecological characteristics of East African drylands. By demonstrating that competition necessarily occurs through vegetative responses, we argue that there is the need to clarify competition by differentiating between 'proximate competition' and competition that is mediated by vegetation change across seasons. The article concludes by outlining the implications of these clarifications for the management and study of livestock-wildlife interactions.
\end{abstract}

Keywords: Competition, East Africa, Livestock, Parks, Pastoralism, Rangeland ecology wildlife

\section{Review}

Introduction

Competition between living organisms is a fundamental concept in ecology (Sommer and Worm 2002). Studies of ecological competition date as far back as the 1920s and have been used to understand species interactions and the structuring of ecological communities. These studies include those focused on theory (Connor and Simberloff 1979; Tilman 1977; Wiens 1984), mathematical modeling (Gause 1934; Lotka 1925; Mead 1967; Volterra 1926), empirical laboratory and field studies (Andrewartha and Birch 1954; Elton 1946; Harper 1977; Tilman 1981; Whittaker 1967), and application to conservation and development practices (Kreuter and Workman 1994; Vavra and Sheehy 1996).

Research that examines the relationships between wildlife and livestock has grown rapidly within the last several decades. However, there remains a great deal of controversy surrounding the characterization of wildlife-livestock relationships. Different scholars from various disciplines have suggested, implied, or stated that domestic livestock 
compete with wildlife over natural resources (Averbeck et al. 2009; Low et al. 2009; Voeten and Prins 1999; Young et al. 2005); livestock facilitate wildlife (Gordon 1988); livestock co-exist or do not compete with wildlife (Homewood et al. 2001; Sitters et al. 2009); or that livestock both facilitate and compete with wildlife (Odadi et al. 2011). Habitat and dietary overlap in the distribution of both wildlife and livestock have often been cited as the primary mechanism by which competition occurs (Beck and Peek 2005; Georgiadis et al. 2007; Madhusudan 2004; Mishra et al. 2004; Prins 1992, Prins 2000; Sitters et al. 2009; Zhongqiu et al. 2008). However, some studies have also argued that a lack of overlap (displacement) is indicative of competition (e.g., Loft et al. 1991; Stewart et al. 2002). As a result, livestock-wildlife competition can be seen as occurring with any degree of dietary or habitat overlap. While either exclusion or overlap could occur in particular situations, the persistent confusion and controversy reflect conceptual problems with how the concept is used to understand livestock-wildlife interactions. Part of the inconsistency associated with characterizing the relationships between wildlife and livestock arises from confusion over the definitions and interpretations associated with the term 'competition' (Wiens 1977, 1984).

Despite recognition of the complexity of competitive processes within the academic literature, use of the term 'competition' to characterize the relationships between wildlife and livestock is common among conservation organizations and in popular media representations of rural peoples, their livestock, and wildlife. ${ }^{a}$ These portrayals reinforce prevailing notions that there is a zero-sum competitive relationship between livestock grazing and wildlife protection, which has contributed to policies favoring restricting livestock grazing and excluding livestock-rearing peoples near protected areas, leading to overt and covert resistance by rural people (Brockington 2002).

How one conceptualizes the relationship between wildlife and livestock is enormously relevant within the East African context $\mathrm{t}^{\mathrm{b}}$ for several reasons. First, wildlife is important to the economy of many countries, such as Kenya, where a large part of the Gross Domestic Product is derived from tourism and wildlife viewing activities (Akama 1998, Akama 2002; Waithaka 2004). Second, the megafauna that are important to the tourism industry also play an important role in ecosystem structure and functioning within the East Africa region and harbor some of the highest densities and distributions of ungulate and mammalian species in the world (Sinclair and Arcese 1995; Sinclair and Norton-Griffiths 1979; Sinclair et al. 2008). Third, livestock are important to sustain rural livelihoods in environmentally variable and heterogeneous rangelands (Ellis and Galvin 1994; Scoones 1994a). Fourth, while pastoralism is a land-use system that is potentially compatible with wildlife, there is a growing spatial overlap with a large proportion of wildlife found outside protected areas (Broten and Said 1995; Lamprey and Reid 2004; Ottichilo et al. 2000; Western et al. 2009) in areas where there are an increasing number of pastoralists (Reid et al. 2001, Reid et al. 2004). Poorly conceptualized understandings of competition have influenced the development and implementation of state and local policies associated with conservation and development, which are likely to have adverse effects on both wildlife and livestock. ${ }^{c}$

The purpose of this article is therefore to clarify the meaning of competition as it relates to wildlife and livestock in dryland Africa, particularly East Africa. ${ }^{\mathrm{d}}$ This article is organized into three parts. First, we argue that unclear notions of competition circulate as common understandings without clarification due in part to its historic 
importance in ecology. We discuss the need to use ecological understandings that define what we mean by competition within the context of characterizing livestock-wildlife competition. Second, we move from general principles of competition to a more refined vision of wildlifelivestock competition and trace the empirical complexities of competition as mediated through vegetative response, which are shaped by climatic variability and spatial scaling. Finally, we move toward an understanding of 'exploitation competition' and outline some of the implications of conceptual clarification for measuring wildlife-livestock competition.

\section{Competition as an ecological concept}

In biological terms, the term competition is often, indeed usually, employed without definition, as if its meaning were perfectly well understood and could be taken for granted.... The result is confusion because competition means different things to different people.

(Milne 1961, pp. 40-41)

Over the last half-century, the application of the concept of competition has been plagued by considerable ambiguity and confusion. As Milne (1961) and Harper (1961) have both argued, the lack of conceptual clarity has been due in part to its ubiquitous nature in ecological thought. A common understanding was often assumed which did not actually exist in practice. This became particularly evident when ecological principles were applied to resource management questions (wildlife, range, fisheries management). We generally have a clear idea of competition in the abstract, but being able to identify it and measure it in the field has proven to be more complicated.

Existing research on competition between wildlife and livestock generally has treated it as interspecific sympatric competition, where individuals of different species vie for the same resource in an ecosystem (Prins 2000). Arguments for or against such competition have relied on dietary overlap (Fritz et al. 1996; Mishra et al. 2004; Odadi et al. 2007; Vila et al. 2009) as evidence for competition. This approach can be as simple as depicting grazers competing with grazers and browsers with browsers. More detailed analyses have relied on comparing forage species preferences (e.g., Madhusudan 2004; Odadi et al. 2011). How diets overlap may or may not be tied, in these analyses, to specific areas where wildlife and livestock graze. The geographies of wildlife and livestock movements may be ignored with conclusions of competition derived from dietary overlap and sharing common zones of movement. More sophisticated attempts have incorporated understandings of wildlife and livestock habitat to either argue for habitat overlap as evidence for ongoing competition or coexistence (Shrestha and Wegge 2008; Voeten and Prins 1999; Yoshihara et al. 2008) or no overlap as evidence for competitive exclusion, avoidance, or no possibility of competition (Loft et al. 1991; Namgail et al. 2007).

There is a need for greater clarity in applying the abstract concept of competition to livestock-wildlife interactions. References to wildlife-livestock competition elicit basic ecological and evolutionary ideas of reduced fitness, competitive exclusion, and population decline (e.g., Odadi et al. 2011; Ogutu et al. 2009b, Ogutu et al. 2011; Stewart et al. 2002). On the contrary, proponents of the 'pastoralist position' often argue for the long-term cohabitation of pastoralists (and their livestock) with wildlife (Homewood and Rodgers 1984, Homewood and Rodgers 1987; Neumann 1998). Still, meaningful competition could 
possibly exist without abrupt population declines. Reduced nutritional status of wildlife or domestic livestock caused by exploitation competition could lead to lower recruitment (e.g., Hobbs et al. 1996), increased vulnerability to disease (e.g., Cleaveland et al. 2008), and emigration out of competitive areas to other areas of higher forage quality (e.g., Serneels and Lambin 2001). Making such connections in non-controlled, real-world situations, has proven very difficult since reduced fitness or population declines of livestock and wildlife are also more strongly shaped by stresses external to their competitive interactions such as droughts, disease, and habitat loss (Homewood et al. 2001). There is a strong need to delineate areas of understanding and uncertainty that surround two basic questions: in what ways can we say wildlife and livestock compete, and to what effect? Clarifying how competition is defined is an important first step toward this goal.

\section{Competition: definitions}

In the late 1980s, Wiens provided a concise definition of ecological competition. He suggested that 'species or populations compete for resources if and when resources from a limited supply are not available or are reduced for one species due to the acts or presence of another species' (Wiens 1989, p. 3). This definition is consistent with that outlined by Milne (1961) and subsequent authors such as Prins (2000, p. 61) who outlines three conditions for interspecific competition: '(1) populations of the different species must share resources; (2) these resources must be limited, and; (3) the joint exploitation of those resources and/or interference interactions related to the resources must negatively affect the performance of either or both species'. According to Wiens (1984), competitive processes can be conceptualized in two ways: competition can occur through interference when resources are denied to individuals because of the aggressive actions of other individuals, or through exploitation, such as in the act of grazing, where limiting resources become scarcer. Although there is some evidence for wildlife avoidance of livestock and herders (e.g., Pangle and Holekamp 2010), wildlifelivestock competition is largely seen as exploitation rather than interference competition (Odadi et al. 2011).

\section{Competition and ecological dynamics}

Wiens (1989) highlights how competition affects individual, population, or community attributes depending on its intensity relative to other factors shaping these attributes. Specifically, he argued that 'competition at times may be quite intense, but nonetheless be relatively unimportant if individual fitness or community attributes are determined largely by other factors. Because there may be variation in the degree to which individuals in a population experience competition, some individuals may be influenced by competition without the effects of these interactions translating into population- or community-level consequences' (emphasis added) (Wiens 1989, p. 5). In fact, a trend beginning in the 1980s has been to question the equilibrium assumptions of the standard models of ecological competition, such as those of Lotka (1925), Volterra (1926), Gause (1934), and Hardin (1960), and in so doing, explain coexistence of species despite competitive interactions (Connell 1983; Schoener 1983; Sommer and Worm 2002). For example, Alley states that, 'the principle of competitive exclusion and the related assumption that communities exist at competitive equilibrium - fundamental parts of many competition theories and models - may be violated if non-equilibrium 
conditions exist in natural communities or are incorporated into competition models' (emphasis added) (Alley 1982, p. 165). In short, the effects of competition on animal populations may be small, particularly in African drylands, relative to other factors external to the competitive interaction in question.

The recognition of spatial heterogeneity has strongly shaped new views about the effect of competition on species composition. Tilman (1994) argued that a spatial model includes neighborhood competition, random dispersal among sites, and predicts stable coexistence of a potentially unlimited number of species on a single resource. Coexistence occurs because species with sufficiently high dispersal rates persist in sites not occupied by superior competitors. Ritchie (2002) likewise noted that it is difficult to determine whether competition occurs among mobile animals. Specifically, Richie argued that 'mobile animal species are highly likely to co-exist because of their ability to move and make choices. These choices result in resource partitioning that allow exclusive use of resources, so that the structure of communities can be predicated largely in the absence of detailed knowledge of competitive dynamics' (Ritchie 2002, p. 109). Clearly in situations such as in East Africa where livestock and wildlife are highly mobile, measuring the competition and its effects is not a straightforward problem.

\section{Livestock-wildlife competition in East Africa}

What is the nature of wildlife-livestock competition in East Africa? Clearly, competitive exclusion solely due to competition between mobile livestock and wildlife is unlikely. Still, a weaker form of competition undoubtedly occurs with effect. It is important to understand its nature. To do so, let's revisit the definition of ecological competition of Wiens (1989) (and adapted by Prins 2000) which requires that in order for competition to occur: (1) resources must be shared; (2) the resource must be 'limiting' to one or both of the animal populations involved; and (3) the availability of the resource must be negatively affected by one or both of the animal populations. Each of these three requirements (shared resource, limiting resource, and negative impact on resource) will be briefly discussed in the context of the competition between pastoral livestock and wildlife in East Africa.

\section{A shared resource}

Overlapping diets and habitat ${ }^{\mathrm{e}}$ are necessary but insufficient conditions for an empirical demonstration of short-term competition. Three mediating factors influence whether overlapping diets and habitat actually results in resource sharing: spatial displacement, selective grazing, and temporal displacement. Studies of grazing and browsing behavior by domestic and wild ungulates of dryland grassland regions in Africa show that grazing to be inherently patchy. Therefore, shared habitats may not result in animals grazing the same forage patches because the foraging behaviors and diets preference of the domestic and wild animals are not the same (Arnold and Dudzinsk 1978). This may be particularly true in relationships between domestic and wild ungulates as the former graze under human management while the latter may graze in areas that allow them to avoid humans (Reid et al. 2004). Even within the same patch, there is often significant but variable degrees of selectivity with respect to forage species (Manser and Brotherton 1995), phenological status of plant (Hiernaux and Turner 1996), plant part (Ayantunde et al. 1999), and physiological state of plant as affected by nutrient and moisture availability (Belsky 1986; McNaughton and Georgiadis 1986). Therefore, grazing by different ungulate species on the same patch 
may not effectively be sharing the same resource. ${ }^{\mathrm{f}}$ Moreover, grazing bouts of different species in a particular patch are most often displaced in time. Depending on the nature of the grazing, the time elapsed since grazing, and the plant community, grazing at one time of year may increase, decrease, or have little effect on the availability of a resource (a plant or plant part) during another time of year (Belsky 1986; Hiernaux and Turner 1996; McNaughton and Georgiadis 1986).

\section{A limiting resource}

Justus von Liebig's concept of a limiting resource (von Liebig 1842), while popular in the ecological and agricultural sciences, has proven difficult to implement especially in the ecosystems of dryland Africa where the biological productivity is multiply constrained with the relative limitation of a given factor varying over time and space. While animal nutrition can be limited by water, mineral availability, heat stress, infectious disease, and parasites, short-term competition between livestock and wildlife is seen as occurring through lowering the availability of fodder (Ogutu et al. 2011). Forage competition changes the energy balance of the grazing activity (units of usable energy per unit of energy expended). Grazing that reduces the availability of forage at the level of the patch may lead to greater energy expenditure by animals to maintain their intake either through less efficient selective grazing or longer movements to grazing patches ${ }^{\mathrm{g}}$ (Ayantunde et al. 1999). Given the relatively high abundance of quality palatable forage for both wild and domestic ungulates during the wet season, immediate competitive pressures are expected to be higher during the dry season as the energy balance of grazing animals become more limited by variations (some due to grazing) in fodder availability. Therefore, competition would be expected to be highest during the dry season when grazing ranges are constricted near available water and when overall fodder quality is lower.

\section{A negative influence on resource availability}

Grazing competition among domestic and wild ungulates is largely displaced in time (Prins 2000). In open range situations, it is uncommon for livestock and the wild ungulates to graze shoulder-to-shoulder on the same forage patch. Therefore, competition necessarily develops through the response of vegetation and soils to wildlife or livestock grazing. In the dry season, vegetation response is minimal and dry sandy soils are relatively insensitive to grazing pressure. Except in cases of heavy grazing in which the removal of thatch exposes soils to erosion from wind and heavy early rains, dry-season grazing simply reduces the stock of dry fodder available causing higher-quality forage to become less available during the same season. ${ }^{\mathrm{h}}$ In contrast, grazing during the rainy season has a greater chance to have longer-term interannual effects. Heavy grazing during the growing season can lead to reductions in grassland production, shifts in species composition, nutrient redistribution, and soil compaction (Augustine 2003; Hiernaux 1998; Hiernaux et al. 1999; Penning de Vries and Djitèye 1982; Ruess and McNaughton 1987; Turner 1999; Veblen 2008). Therefore, while competition effects are most likely felt (e.g., a limiting resource) during the dry season, these effects are largely generated through grazing activities during the rainy season.

In the dryland environments of sub-Saharan Africa, the nutrition and population dynamics of livestock (Behnke et al. 1993; Ellis and Swift 1988; Illius and O'Connor 1999; Sullivan and Rohde 2002) and wildlife (Hopcraft et al. 2010; Ogutu et al. 2009a) 
are strongly affected by factors external to the grazer-forage relationship, most particularly climate. Whether conceptualized as non-equilibrium systems or not, wildlife-livestock competition, as mediated through vegetative response to grazing, may have a small effect relative to the high variability in conditions affecting vegetation, livestock, and wildlife. There are many factors influencing domestic and wild animal populations external to the competitive relations among grazing animals. For example, studies of domestic livestock (e.g., Ellis and Swift 1988; Scoones 1993, Scoones 1994b; Sullivan and Rohde 2002) and wildlife (Georgiadis et al. 2003, Georgiadis et al. 2007) population dynamics in dryland Africa find that they are often 'density independent' with variations in population growth rate unrelated to the size of the population. Moreover, nutritional studies also show that the seasonal variation in the quality of the vegetation often is a more important factor affecting animal nutrition than the stocking density of the broad areas over which wild and domestic ungulates circulate across the year (e.g., Ayantunde et al. 1999; Fernández-Rivera et al. 2005; Milner-Gulland et al. 2011). Dryland vegetative productivity has been found to be shaped less by recent grazing history (unless very heavy) than by longer-term grazing history coupled with seasonal and interannual rainfall variation (e.g., Hiernaux and Turner 1996; Penning de Vries and Djitèye 1982; Turner 1999). In sum, if one ignores the strong influence of rainfall variation in dryland systems, one is likely to over-estimate the relative importance of competition in affecting livestock or wildlife. Many conservation and development policies often fail to recognize the seasonal variability in rainfall, which strongly affects forage growth (Butt 2010a). This variability also strongly influences the resource access strategies of domestic livestock (Butt 2010b). There is little acknowledgment of seasonal variation and differential space-time utilization of forage resources by both wildlife and livestock in the few published conservation planning initiatives.

\section{Unpacking exploitation competition in East Africa}

In order to effectively move beyond conceptualizations of competition as related to overlap and/or displacement, there is the need to further unpack the notion of exploitation competition in a way that is relevant to dryland East Africa. A necessary condition for 'exploitation competition' is that the actions of one population meaningfully limit the availability of forage for the other population. The high seasonality of vegetation productivity in rangeland environments of East Africa (Butt 2010a; Deshmukh 1986) strongly shapes the potential for competition. It is rare for grazing-induced forage shortage to significantly limit ungulate nutrition during the wet season when vegetation is most sensitive to grazing (Voeten and Prins 1999). Vegetation is much more resilient to dry season grazing when forage is limiting to grazing ungulates (McNaughton 1985, Mworia et al. 1997). Therefore, we wish to distinguish two types of exploitation competition, which can occur during the dry season.

The first is the grazing competition for quality forage as the dry season progresses and the availability of digestible forage declines. Competition occurs through the direct effect of one population consuming what the other population would have consumed within later weeks. This is most close to current conceptualizations of competition held by wildlife managers - one ungulate's consumption literally takes quality forage away from another. This more proximate form of exploitation competition is necessarily associated with grazing overlap between wildlife and domestic livestock in space and time. This 
overlap can occur at the scale of weeks to months. It is most common where grazing movements are restricted to those areas near more permanent water sources and pastoral settlements. Drought conditions can exacerbate these competitive pressures through the reduction in surface water and/or forage. Proximate competition occurs during periods and at places where quality forage availability is already limited, whether or not a competing population is present. Under these situations, all ungulate species are generally competing between and among each other, and the amount of forage removed through the actions of others is very small relative to annual forage requirements. ${ }^{j}$ Nonetheless, a decline in a population's access to nutritional quality may have, in difficult years, a significant effect on survivorship.

The second type of exploitation competition is more displaced in time. Given the important effects of rainy-season grazing on the quality and quantity of forage production (as influenced by species composition and productivity of rangelands), a major mechanism through which competition could occur in drylands is the reduction of forage availability during the dry season caused by wet-season grazing. These conditions can exist within the same year or interannually. In these cases, competition is displaced over time. The negative impacts of this form of competition on forage availability are potentially much larger than the effects of proximate competition but they have proven to be more difficult to empirically document.

\section{Implications for future research}

Given the porosity of their borders, wildlife and livestock graze inside and outside of protected areas in East Africa (Peden 1987; Reid et al. 2001, Reid et al. 2003; Western 1982; Western et al. 2009). We therefore need to build our understanding of wildlifelivestock competition to better manage the mixed grazing, farming, and wildlife landscapes of East Africa. Despite common misperceptions, evidence, as described above, suggests that wildlife-livestock competition does not lead to competitive exclusion and may have a smaller impact on wildlife and livestock populations than factors external to the wildlife-livestock interaction. Other factors such as drought, habitat/ pasture loss due to agriculture, disease, and hunting/predation are likely to more significantly influence the viability of wildlife and livestock populations (Homewood et al. 2001). Still competition undoubtedly occurs with an effect on the grazing strategies and grazing efficiencies of these populations. As discussed previously, we cannot infer competition simply from the sharing of a preferred resource or space (dietary or habitat overlap). The resource must be the same, limiting, and negatively affected by the activities of the other species. Where attempts have been made to move beyond diet/habitat overlap, researchers have relied on experimental designs where wildlife and livestock are enclosed in fenced pastures. For example, the effects of wildlife and livestock on vegetation are often conducted through timed runs within experimental blocks measuring a few hectares (Odadi et al. 2007; Young et al. 1998). While such work provides insights on the mechanisms behind competition, they provide little information about the nature of wildlife-livestock interactions in less-controlled, real-world situations where pastoral livestock and wildlife are highly mobile and the variability of external factors are strongly felt.

Given these circumstances, there is a strong need to combine the insights of such experimental work with field studies that more seriously address the complex contexts 
within which wildlife-livestock competition occurs. Our review points to a number of features that new research should incorporate.

First, empirical analysis of wildlife-livestock competition requires more thorough analyses of how 'proximate competition' influences wildlife and domestic livestock nutrition as forage scarcity increases during the dry season. There are significant questions with respect to interspecific grazing interactions, selective grazing, and changing heterogeneity of forage quality in pasture areas around the key resources relied upon by domestic livestock and wildlife populations during the dry season (Ngugi and Conant 2008). Animal nutrition and range ecology work focused on this question should be performed around key seasonally variable resources used by wildlife and livestock.

Second, wildlife and livestock competition is most likely to be displaced in time as mediated through vegetative response to rainy-season grazing. Wildlife-livestock competition research, which has been dominated by wildlife ecologists, must more seriously address range ecology. In particular, future research must address how both forage quality and quantity change with respect to differential grazing pressures within and across seasons. Given that rangelands are characterized by spatially and temporally heterogeneous landscapes with a variety of different land covers, soil types, and rainfall gradients, there is the need to understand how these factors influence above ground biomass and forage quality.

Third, there is a need for greater spatial specificity of livestock and wildlife grazing and browsing patterns to understand their true overlap across time. While radio collaring has been a standard approach in wildlife ecology for some time, more spatially refined documentation of the grazing 'orbits' of pastoral-managed livestock has only recently been developed (Butt 2010b, 2011; Coppolillo 2000). Moreover, pastoralists or community groups themselves will provide very useful information about landscape change and the interactions of domestic and wild ungulates in the bush (Goldman 2007; Low et al. 2009; Msoffe et al. 2010; Oba and Kaitira 2006).

Finally, wildlife-livestock interaction needs to be studied in particular places given the temporal displacement inherent to nutritional consequences of grazing. Grazing occurs in different places at different times of the year. Vegetative response is most sensitive to grazing during the rainy season, while forage is most limited during the dry season. Therefore, future research should aim to monitor grazing and vegetative response across at least an annual cycle, rather than solely during dry periods.

\section{Conclusions}

In this article, we have discussed the importance that wildlife and livestock play in the ecology and economy of East African countries. A review of the scientific literature suggests that the term 'competition' has been used to characterize the relationships between wildlife and pastoral livestock and reveals that competition has been perceived as occurring with any degree of habitat or dietary overlap. We have demonstrated how characterizing the relationships between wildlife and pastoral livestock as competition is problematic given the vague definitions and contexts associated with the concept. To help clarify 'competition, we have traced the history, definitions, and ecological dynamics associated with the concept. We then discuss the three conditions necessary for competition to occur (a shared resource, a limiting resource, and a negative influence on resource availability) within the context of pastoral managed livestock and wildlife in dryland regions of Africa. This 
literature suggests that wildlife-livestock competition is largely exploitative. However, exploitation competition is mediated through vegetative responses to grazing, which are shaped by climatic variability, grazing selectivity, and patchiness, which vary across heterogeneous landscapes in both time and space.

Both wild ungulates and domestic livestock are mobile and competition between them can only occur if their grazing occurs at the same place. Vegetative change is most associated with grazing during the growing season - a time when forage availability is less limiting to animal nutrition. Therefore, competition that is seasonally displaced (grazing in one season affects vegetation and animal nutrition in subsequent seasons) is the most prevalent form of competition but at the same time the most subtle and difficult to investigate. Evidence of such competition necessarily is vegetative change - requiring greater understanding of vegetative ecology than is typical for wildlife managers. We have argued that in order to move beyond conceptualizations of competition that are rooted in dietary overlap and/or displacement, there is the need to clarify exploitation competition by differentiating between competition that occurs over a fixed resource or 'proximate competition' and that which is mediated through vegetative response to grazing at an earlier time. The former is associated with forage reductions during the dry season when there is not vegetative growth, while the latter is most associated with wet season grazing where the competitive effects of grazing are mediated by vegetative response (changes in species composition and productivity) and is felt across seasons. We end the article by providing a number of implications for future research, which should be focused on less controlled, real-world situations. These recommendations include focusing on the nutritional implications for wildlife and livestock as forage quantity decreases; the vegetative responses to grazing within and across seasons; greater spatial specificity of wildlife and livestock grazing patterns; and specific grazing locations across the entire seasonal calendar.

Increased rigor in thinking about the competition among wildlife and livestock not only leads to the identification of important areas for further research (areas of uncertainty), but also reveals areas of relative certainty to guide policy particularly related to wildlife protection and management. Contrary to popular impression, the presence or absence of dietary or habitat overlap is insufficient to claim competition between livestock or wildlife. Such arguments provide little room for mutually beneficial use of common rangeland resources by wildlife and livestock for which there is historical and contemporary evidence (Homewood and Rodgers 1987; Little 1996). Such thinking not only leads to over-estimations of competition, but also leads to land-use decisions that exclude grazing wildlife from pasturelands or livestock from protected areas - decisions that will increase the vulnerability of the whole wildlife-livestock-grassland system.

\section{Endnotes}

${ }^{a} \mathrm{~A}$ recent example of this appeared on the BBC's Earth News section online on June 4, 2010. Through a series of pictures depicting declining populations of Grevy's Zebra in Kenya, an accompanying storyline suggests, 'the diet of Zebra might overlap with competing livestock' (BBC 2010). Similarly, a well-known environmental news magazine cited a study in the Journal of Zoology (Ogutu et al. 2009b) whereby 'wildlife populations in Masai Mara are plummeting due to increased competition with humans and livestock' (Hance 2009). 
${ }^{\mathrm{b}}$ Our primary focus in this article is on East Africa for a number of reasons. First, as we have noted above, how one conceptualizes the relationship between wildlife and livestock in east African drylands has social, political, economic, and cultural significance. Second, our backgrounds and cited references come from dryland African material. Third, East Africa is the sub-region where debates about competition among wildlife and domestic livestock are prominent and have become particularly heightened within the past decade. These tensions have shaped conservation and development initiatives in this part of the world. Finally, the East African context is drawn from our own ongoing empirical investigations into wildlife-livestock competition within southern Kenya.

${ }^{c}$ For example, World Wildlife Fund (WWF) Biodiversity Support Program writes on their website that 'In Awash National Park, encroachment and settlement led to the illegal harvest of fuel wood and shelter wood, increased competition between wildlife and livestock, and forced many species to forage elsewhere' (Jacobs and Schloeder 2001).

${ }^{\mathrm{d}}$ In this article, we are primarily concerned with conservation and wildlife policies insofar as they relate to wildlife interactions with livestock in dryland environments. We are also concerned with the effects of livestock on wildlife, and not the effects of wildlife on livestock. Wildlife is defined as wild grazing ungulates and livestock as domestic cattle, sheep, goats, and camels.

${ }^{\mathrm{e}}$ Habitats refer to ecosystems with particular ecological and physical characteristics suited for a particular species to inhabit. They can be referred to in abstract or as particular places over variable spatial extent utilized by an animal population.

${ }^{\mathrm{f}}$ Grazing of different forage species in the same patch may actually influence the availability of the other over time.

${ }^{g}$ Given that forage species preference is strongly shaped by overall forage composition, the nutritional consequences of competition over a particular forage species may not necessarily be significantly negative since declines in the availability of one species may result in switching to another species of lower palatability but similar nutritive content.

${ }^{\mathrm{h}}$ Given the poor quality of dry grass during the dry season, dry-season grazing is selective and dry-season grazing generally does not lead to full exposure of soil (Deshmukh 1984, Deshmukh 1986).

i Termites may as well be important competitors with both livestock and wild ungulates for dry vegetation (e.g., Hopcraft 2000, p. 271; Newsome 1971).

'At sites where the quality of dry forage is ubiquitously low, grazing by a population may not have a significantly negative effect on the nutrition of another since it is the quality of the forage that is most limiting not its quantity. Therefore, we may see the potential for proximate dry-season competition to decline as the dry season progresses and the heterogeneity of forage quality declines. 


\section{Author details}

${ }^{1}$ School of Natural Resources and Environment, University of Michigan, Ann Arbor MI 48109-1041, USA. ${ }^{2}$ Department of Geography, University of Wisconsin, Madison, WI 53706, USA.

\section{Received: 5 October 2011 Accepted: 10 January 2012}

Published: 28 September 2012

\section{References}

Akama JS (1998) The evolution of wildlife conservation policies in Kenya. Journal of Third World Studies 15:103-117 Akama JS (2002) The role of Government in the development of tourism in Kenya. International Journal of Tourism Research 4:1-14

Alley TR (1982) Competition theory, evolution, and the concept of an ecological niche. Acta Biotheor 31:165-179 Andrewartha HG, Birch C (1954) The distribution and abundance of animals. University of Chicago Press, Chicago Arnold GW, Dudzinsk ML (1978) Ethology of free-ranging domestic animals. Developmens in Animal and Veterinary Science 2. Elsevier, Amsterdam

Augustine DJ (2003) Long-term, livestock-mediated redistribution of nitrogen and phosphorus in an East African savanna. J Appl Ecol 40:137-149

Averbeck C, Apio A, Plath M, Wronski T (2009) Environmental parameters and anthropogenic effects predicting the spatial distribution of wild ungulates in the Akagera savannah ecosystem. Afr J Ecol 47:756-766

Ayantunde A, Hiernaux P, Fernandez-Rivera S, van Keulen H, Udo HMJ (1999) Selective grazing by cattle on spatially and seasonally heterogeneous rangeland in Sahel. J Arid Environ 42:261-279

BBC (2010) In Pictures: Grevy's zebra., http://news.bbc.co.uk/earth/hi/earth_news/newsid_8719000/8719473.stm Accessed 08 Nov 2010

Beck JL, Peek JM (2005) Diet composition, forage selection, and potential for forage competition among elk, deer, and livestock on aspen-sagebrush summer range. Rangel Ecol Manage 58:135-147

Behnke RH, Scoones I, Kerven C (1993) Range ecology at disequilibrium: New models of natural variability and pastoral adaptation in African savannas. Overseas Development Institute, London

Belsky AJ (1986) Does herbivory benefit plants? A review of the evidence. Am Nat 127:870-892

Brockington D (2002) Fortress conservation: The preservation of the Mkomazi Game Reserve, Tanzania. James Currey, Oxford

Broten M, Said M (1995) Population trends of ungulates in and around Kenya's Masai Mara Reserve. In: Sinclair ARE, Arcese P (eds) Serengeti II: Dynamics, management and conservation of an ecosystem. University of Chicago Press, Chicago, pp 169-193

Butt B (2010a) Pastoral resource access and utilization: Quantifying the spatial and temporal relationships between livestock mobility, density and biomass availability in southern Kenya. Land Degradation and Development 21: $520-539$

Butt B (2010b) Seasonal space-time dynamics of cattle behavior and mobility among Maasai pastoralists in semi-arid Kenya. J Arid Environ 74:403-413

Butt B (2011) Coping with uncertainty and variability: The influence of protected areas on pastoral herding strategies in East Africa. Hum Ecol 39:289-307

Cleaveland S, Packer C, Hampson K, Kaare M, Kock R, Craft M, Lembo T, Mlengeya T, Dobson A (2008) The multiple roles of infectious diseases in the serengeti ecosystem. In: Sinclair ARE, Packer C, Mduma S, Fryxell JM (eds) In Serengeti III: Human impacts on dynamic ecosystems. University of Chicago Press, Chicago, pp 209-240

Connell JH (1983) On the prevalence and relative importance of interspecific competition: Evidence from field experiments. American Naturality 122:661-696

Connor EF, Simberloff D (1979) The assembly of species communities; Chance or competition. Ecology 60:1132-1140

Coppolillo PB (2000) The landscape ecology of pastoral herding: Spatial analysis of land use and livestock production in East Africa. Hum Ecol 28:527-560

Deshmukh I (1984) Common relationship between precipitation and grassland peak biomass for East and Southern Africa. Afr J Ecol 22:181-186

Deshmukh I (1986) Primary production of a grassland in Nairobi National Park, Kenya. J Appl Ecol 23:115-123

Ellis J, Galvin KA (1994) Climate patterns and land-use practices in the dry zones of Africa. Bioscience 44:340-349

Ellis J, Swift DM (1988) Stability of African pastoral ecosystems: Alternate paradigms and implications for development. J Range Manage 41:450-459

Elton CS (1946) Competition and the structure of ecological communities. J Anim Ecol 15:54-68

Fernández-Rivera S, Hiernaux P, Williams TO, Turner MD, Schlecht E, Salla A (2005) Nutritional constraints to grazing ruminants in the millet-cowpea-livestock farming system of the Sahel. In: Ayantunde AA, Fernández-Rivera S, McCrabb G (eds) Coping with feed scarcity in smallholder livestock systems in developing countries. International Livestock Research Institute, Nairobi, pp 157-182

Fritz H, de Garine-Wichatitsky M, Letessier G (1996) Habitat use by sympatric wild and domestic herbivores in an African savanna woodland: The influence of cattle spatial behaviour. J Appl Ecol 33:589-598

Gause GF (1934) The struggle for existence. Williams \& Wilkins Company, Baltimore

Georgiadis N, Hack M, Turpin K (2003) The influence of rainfall on zebra population dynamics: implications for management. J Appl Ecol 40:125-136

Georgiadis N, Olwero JGN, Ojwang G, Romañach SS (2007) Savanna herbivore dynamics in a livestock-dominated landscape: I. Dependence on land use, rainfall, density, and time. Biol Conserv 137:461-472

Goldman M (2007) Tracking wildebeest, locating knowledge: Maasai and conservation biology understandings of wildebeest behavior in Northern Tanzania. Environment and Planning D Society and Space 25:307-331

Gordon IJ (1988) Facilitation of red deer grazing by cattle and its impact on red deer performance. J Appl Ecol 25:1-9

Hance J (2009) Famous Kenyan park experiencing large declines in wildlife., http://news.mongabay.com/2009/0421 hance_masaimara.html Accessed 21 Aug 2011 
Hardin G (1960) The competitive exclusion principle. Science 131:1292-1297

Harper D (1961) Approaches to the study of plant competition. In Mechanisms in biological competition symposia of the society for experimental biology, XV, 1-39. Cambridge University Press, Cambridge

Harper D (1977) The population biology of plants. Academic Press, New York

Hiernaux P (1998) Effects of grazing on plant species composition and spatial distribution in rangelands of the Sahel. Plant Ecology 138:191-202

Hiernaux P, Bielders CL, Valentin C, Bationo A, Fernandez-Rivera S (1999) Effects of livestock grazing on physical and chemical properties of sandy soils in Sahelian rangelands. J Arid Environ 41:231-245

Hiernaux P, Turner MD (1996) The effect of clipping on growth and nutrient uptake of Sahelian annual rangelands. J Appl Ecol 33:387-399

Hobbs NT, Baker DL, Bear GD, Bowden DC (1996) Ungulate grazing in Sagebrush grassland: Effects of resource competition on secondary production. Ecol Appl 6:218-227

Homewood K, Lambin EF, Coast E, Kariuki A, Kikula I, Kivelia J, Said M, Serneels S, Thompson M (2001) Long-term changes in Serengeti-Mara wildebeest and land cover: Pastoralism, population, or policies? Proc Natl Acad Sci U S A 98:12544-12549

Homewood K, Rodgers W (1987) Pastoralism, conservation and the overgrazing controversy. In: Anderson D, Grove R (eds) Conservation in Africa. Cambridge University Press, Cambridge, pp 111-128

Homewood K, Rodgers W (1984) Pastoralism and conservation. Hum Ecol 12:431-441

Hopcraft D (2000) Wildlife land use and the great experiment. In: Prins HHT, Grootenhuis JG, Dolan TT (eds) Wildlife conservation by sustainable use. Kluwer Academic Publishers, Boston, pp 267-275

Hopcraft JGC, Olff H, Sinclair ARE (2010) Herbivores, resources and risks: Alternating regulation along primary environmental gradients in savannas. Trends Ecol Evol 25:119-128

Illius AW, O'Connor TG (1999) On the relevance of nonequilibrium concepts to arid and semiarid grazing systems. Ecol Appl 9:798-813

Jacobs MJ, Schloeder CA (2001) Impacts of conflict on biodiversity and protected areas in Ethiopia. Biodiversity Support Program.WWF, Washington, DC

Kreuter UP, Workman JP (1994) Government policy effects on cattle and wildlife ranching profits in Zimbabwe. J Range Manage 47:264-269

Lamprey RH, Reid RS (2004) Expansion of human settlement in Kenya's Maasai Mara: What future for pastoralism and wildlife? J Biogeogr 31:997-1032

Little PD (1996) Pastoralism, biodiversity, and the shaping of savanna landscapes in East Africa. Africa 66:37-51

Loft ER, Menke JW, Kie JG (1991) Habitat shifts by mule deer: The influence of cattle grazing. Journal of Wildlife Management 55:16-26

Lotka AJ (1925) Elements of physical biology. Williams \& Wilkins Company, Baltimore

Low B, Sundaresan SR, Fischhoff IR, Rubenstein DI (2009) Partnering with local communities to identify conservation priorities for endangered Grevy's zebra. Biol Conserv 142:1548-1555

Madhusudan MD (2004) Recovery of wild large herbivores following livestock decline in a tropical Indian wildlife reserve. J Appl Ecol 41:858-869

Manser MB, Brotherton PNM (1995) Environmental constraints on the foraging behavior of a Dwarf Antelope (Madoqua-Kirkii). Oecologia 102:404-412

McNaughton SJ (1985) Ecology of a Grazing System: The Serengeti. Ecological Monographs 55: 259-294

McNaughton SJ, Georgiadis NJ (1986) Ecology of African grazing and browsing mammals. Annual Review of Ecology and Systematics 17:39-65

Mead R (1967) A mathematical model for the estimation of inter-plant competition. Biometrics 23:189-205

Milne A (1961) Definition of competition among animals. In Mechanisms in biological competition symposia of the society for experimental biology XV, 40-61. Cambridge University Press, Cambridge

Milner-Gulland EJ, Fryxell JM, Sinclair ARE (2011) Animal migration: A synthesis. Oxford University Press, Oxford

Mishra C, Prins HHT, Van Wieren SE, Ketner P, Heitkönig IMA (2004) Competition between domestic livestock and wild bharal Pseudois nayaur in the Indian Trans-Himalaya. J Appl Ecol 41:344-354

Msoffe FU, Ogutu JO, Kaaya J, Bedelian C, Said MY, Kifugo SC, Reid RS, Neselle M, van Gardingen P, Thirgood S (2010) Participatory wildlife surveys in communal lands: a case study from Simanjiro, Tanzania. Afr J Ecol 48:727-735

Mworia JK, Mnene WM, Musembi DK, Reid RS (1997 ) Resilience of soils and vegetation subjected to different grazing intensities in a semi-arid rangeland of Kenya. African Journal of Range \& Forage Science 14:26-31

Namgail T, Fox JL, Bhatnagar YV (2007) Habitat shift and time budget of the Tibetan argali: The influence of livestock grazing. Ecological Research 22:25-31

Neumann R (1998) Imposing wilderness: Struggles over livelihood and nature preservation in Africa. University of California Press, Berkeley

Newsome AE (1971) Competition between wildlife and domestick livestock. Aust Vet J 47:577-586

Ngugi MK, Conant RT (2008) Ecological and social characterization of key resource areas in Kenyan rangelands. J Arid Environ 72:820-835

Oba G, Kaitira LM (2006) Herder knowledge of landscape assessments in arid rangelands in northern Tanzania. J Arid Environ 66:168-186

Odadi WO, Karachi M, Abdulrazak S, Young TP (2011) African wild ngulates compete with or facilitate cattle depending on season. Science 333:1753-1755

Odadi WO, Young TP, Okeyo-Owuor JB (2007) Effects of wildlife on cattle diets in Laikipia rangeland, Kenya. Rangel Ecol Manage 60:179-185

Ogutu J, Piepho HP, Dublin HT, Bhola N, Reid R (2009a) Rainfall extremes explain interannual shifts in timing and synchrony of calving in topi and warthog. Population Ecology 52:89-102

Ogutu J, Piepho HP, Dublin HT, Bhola N, Reid RS (2009b) Dynamics of Mara Serengeti ungulates in relation to land use changes. J Zool 278:1-14 
Ogutu JO, Owen-Smith N, Piepho HP, Said MY (2011) Continuing wildlife population declines and range contraction in the Mara region of Kenya during 1977-2009. J Zool 285:99-109

Ottichilo WK, Said MY, de Leeuw J, Skidmore AK, Prins HHT (2000) Population trends of large non-migratory wild herbivores and livestock in the Masai Mara ecosystem, Kenya, between 1977 and 1997. Afr J Ecol 38:202-216

Pangle WM, Holekamp KE (2010) Lethal and nonlethal anthropogenic effects on spotted hyenas in the Masai Mara National Reserve. J Mammal 91:154-164

Peden DG (1987) Livestock and wildlife population distributions in relation to aridity and human populations in Kenya. J Range Manage 40:67-71

Penning de Vries FWT, Djitèye MA (1982) La productivité des pâturages sahéliens. Centre for Agricultural Publishing and Documentation, Wageningen

Prins HHT (1992) The pastoral road to extinction: Competition between wildlife and traditional pastoralism in East Africa. Environmental Conservation 19:117-123

Prins HHT (2000) Competition between wildlife and livestock in Africa. In: Prins HHT, Grootenhuis JG, Dolan TT (eds) Wildlife conservation by sustainable use. Kluwer Academic Publishers, Boston, pp 51-80

Reid R, Rainy M, Ogutu J, Kruska R, McCartney M, Nyabenge M, Kimani K, Kshatriya M, Worden J, Ng'ang'a L, Owuor J, Kinoti J, Njuguna E, Wilson C, Lamprey R (2003) People, wildlife and livestock in the Mara ecosystem: the Mara count 2002, Report, Mara Count 2002. International Livestock Research Institute, Nairobi

Reid R, Thornton PK, Kruska R (2004) Loss and fragmentation of habitat for pastoral people and wildlife in east Africa: Concepts and issues. African Journal of Range and Forage Science 21:171-181

Reid R, Rainy ME, Wilson CJ, Harris E, Kruska RL, Waweru MN, MacMillan SA, Worden JS (2001) Wildlife cluster around pastoral settlements in Africa, creating multiple species associations of wildlife, livestock and people, PLE Science Series \# 2. International Livestock Research Institute, Nairobi

Ritchie ME (2002) Competition and coexistence of mobile animals. In: Sommer U, Worm B (eds) Competition and coexistence. Springer, Berlin, pp 109-132

Ruess RW, McNaughton SJ (1987) Grazing and the dynamics of nutrient and energy regulated microbial processes in the Serengeti Grasslands. Oikos 49:101-110

Schoener TW (1983) Field experiments on interspecific competition. Am Nat 122:240-285

Scoones I (1993) Why are there so many animals? Cattle population dynamics in the communal areas of Zimbabwe. In: Behnke R, Kerven C (eds) Range ecology at disequilibrium: new models of natural variability and pastoral adaptation in African savannas. Overseas Development Institute, London, pp 62-76

Scoones I (1994a) Living with uncertainty: new directions in pastoral development in Africa. Intermediate Technology Publications, London

Scoones I (1994b) New directions in pastoral development in Africa. In: Scoones I (ed) Living with uncertainty: New directions in pastoral development in Africa. Intermediate Technology Publications Ltd., London, pp 1-36

Serneels S, Lambin EF (2001) Impact of land-use changes on the wildebeest migration in the northern part of the Serengeti-Mara ecosystem. J Biogeogr 28:391-407

Shrestha R, Wegge P (2008) Wild sheep and livestock in Nepal Trans-Himalaya: Coexistence or competition? Environmental Conservation 35:125-136

Sinclair ARE, Packer C, Mduma S, Fryxell JM (eds) (2008) Serengeti III: Human impacts on ecosystem dynamics. University of Chicago Press, Chicago

Sinclair ARE, Arcese P (eds) (1995) Serengeti II: Dynamics, management, and conservation of an ecosystem. University of Chicago Press, Chicago

Sinclair ARE, Norton-Griffiths M (eds) (1979) Serengeti, dynamics of an ecosystem. University of Chicago Press, Chicago

Sitters J, Heitnig IMA, Holmgren M, Ojwang GSO (2009) Herded cattle and wild grazers partition water but share forage resources during dry years in East African savannas. Biol Conserv 142:738-750

Sommer U, Worm B (2002) Competition and coexistence. Springer-Verlag, Berlin

Stewart KM, Bowyer RT, Kie JG, Cimon NJ, Johnson BK, O'Shea TJ (2002) Temporospatial distributions of elk, mule deer, and cattle: Resource partitioning and competitive displacement. J Mammal 83:229-244

Sullivan S, Rohde R (2002) On non-equilibrium in arid and semi-arid grazing systems. J Biogeogr 29:1595-1618

Tilman D (1977) Resource competition between planktonic algae: Experimental and theoretical approach. Ecology 58:338-348

Tilman D (1981) Tests of resource competition theory using four species of Lake Michigan Algae. Ecology 62:802-815

Tilman D (1994) Competition and biodiversity in spatially structured habitats. Ecology 75:2-16

Turner MD (1999) Spatial and temporal scaling of grazing impact on the species composition and productivity of Sahelian annual grasslands. J Arid Environ 41:277-297

Vavra M, Sheehy D (1996) Improving elk habitat characteristics with livestock grazing. Rangelands 18:182-185

Veblen KE (2008) Season- and herbivore-dependent competition and facilitation in a semiarid savanna. Ecology 89:1532-1540

Vila AR, Borrelli L, Martinez L (2009) Dietary overlap between huemul and livestock in Los Alerces National Park, Argentina. Journal of Wildlife Management 73:368-373

Voeten MM, Prins HHT (1999) Resource partitioning between sympatric wild and domestic herbivores in the Tarangire region of Tanzania. Oecologia 120:287-294

Volterra V (1926) Variazioni e fluttuazioni del numero d'individui in specie animali conviventi. Memoria della Regia Accademia Nazionale dei Lincei, ser. 6(2):31-113

von Liebig J (1842) Chemistry in its application to agriculture and physiology. Taylor \& Walton, London

Waithaka J (2004) Maasai Mara: An ecosystem under siege: an African case study on the societal dimension of rangeland conservation. African Journal of Range and Forage Science 21:79-88

Western D (1982) Amboseli National Park: Enlisting landowners to conserve migratory wildlife. Ambio 11:302-308

Western D, Russell S, Cuthill I (2009) The status of wildlife in protected areas compared to non-protected areas of Kenya. PLoS One 4:1-6

Whittaker RH (1967) Gradient analysis of vegetation. Biol Rev 42:207-264 
Wiens JA (1977) Competition and variable environments. Am Sci 65:590-597

Wiens JA (1984) On understanding a nonequilibrium world: Myth and reality in community patterns and processes. In: Strong DR, Simberloff D, Abele LG, Thistle AB (eds) Ecological communities: Conceptual issues and the evidence. Princeton University Press, Princeton, pp 439-457

Wiens JA (1989) The ecology of bird communities, vol 2. Cambridge University Press, Cambridge

Yoshihara Y, Ito TY, Lhagvasuren B, Takatsuki s (2008) A comparison of food resources used by Mongolian gazelles and sympatric livestock in three areas in Mongolia. J Arid Environ 72:48-55

Young TP, Okello B, Kinyua D, Palmer T (1998) KLEE: A long-term multi-species herbivore exclusion experiment in Laikipia, Kenya. African Journal of Range and Forage Science 14:92-104

Young TP, Palmer T, Gadd ME (2005) Competition and compensation among cattle, zebras, and elephants in a semiarid savanna in Laikipia, Kenya. Biol Conserv 122:351-359

Zhongqiu LI, Zhigang J, Chunwang LI (2008) Dietary overlap of Przewalski's Gazelle, Tibetan Gazelle, and Tibetan Sheep on the Qinghai-Tibet Plateau. Journal of Wildlife Management 72:944-948

doi:10.1186/2041-7136-2-9

Cite this article as: Butt and Turner: Clarifying competition: the case of wildlife and pastoral livestock in East Africa. Pastoralism: Research, Policy and Practice 2012 2:9.

Submit your manuscript to a SpringerOpen ${ }^{\circ}$ journal and benefit from:

- Convenient online submission

Rigorous peer review

- Immediate publication on acceptance

- Open access: articles freely available online

- High visibility within the field

Retaining the copyright to your article

Submit your next manuscript at $\gg$ springeropen.com 